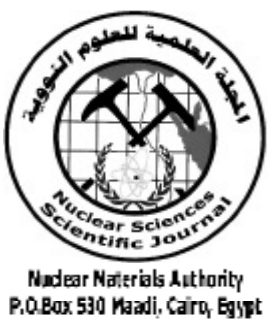

ISSN 2314-5609

Nuclear Sciences Scientific Journal

vol. 4, p163-176

2015

\title{
PHYSICAL AND CHEMICAL CHARACTERISTICS OF GHAZALLAT REGION, SIWA OASIS, WESTERN DESERT, EGYPT
}

\author{
MOHAMED A. HAMMAD; MOHAMED A. HUSSEIN ; MOSTAFA E. DARWISH ${ }^{1}$; \\ FATHY A. AMMAR ${ }^{1}$ and ADEL G. AHMED

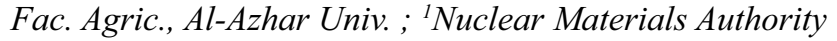

\begin{abstract}
Siwa Oasis is a closed depression situated in the north western portion of the Western Desert of Egypt between Longitudes $25^{\circ} 16^{\prime}$ and $26^{\circ} 12^{\prime}$ E, and Latitudes $29^{\circ} 06^{\prime}$ and $29^{\circ} 24^{\prime} \mathrm{N}$.

Three soil profiles were selected to represent the main geomorphic units and their associated soil groups in the studied area.

Ghazallat soils are characterized mainly by sand and sandy loam textures, as well as sandy clay loam in the deeper layers.

The chemical analyses of soil solution indicate that the cultivated soil samples show slightly saline to moderately saline nature, whereas the soils under reclamation and the barren ones are strongly saline. In general the organic matter contents are low, while $\mathrm{CaCo} 3$ content increases from the deeper samples to the higher ones. As for the soil reaction of Ghazallat area, it is clear that these soils are ranging from mildly to moderately alkaline. It is noticed that $\mathrm{Na}^{+}$cation $>\mathrm{Mg}^{++}, \mathrm{Ca}^{++}$and $\mathrm{Mg}^{++}$. The predominance of $\mathrm{Na}^{+}$and $\mathrm{Mg}^{++}$is a good reflection of the involvement of marine origin of the soils. On the other hand, the anionic distribution has the following descending order $\mathrm{Cl}^{-}$anion $>\mathrm{SO}_{4}^{--}>\mathrm{HCO}_{3}^{-}$, where $\mathrm{CO}_{3}^{-}$is almost negligible. The distribution of the fertility elements are of low to moderate levels.

The bulk samples analysis indicates that quartz, calcite, feldspars (albite) minerals are the main dominant mineral associations in all soil profiles of Ghazallat region. Dolomite and anhydrite as well as gypsum presented in some depths of soil profiles. Illite and kaolinite represent the identified clay minerals in the studied soil samples.

The radiometric studies show that all of the studied soils in the area are not related to the uraniferous soils (uranium content not exceeding 6ppm).

\section{INTRODUCTION}

It is well known that Egypt area is about one million square kilometer, mainly of desert lands with the exception of a small cultivated area concentrated in the River Nile Valley and Delta, occupying about $4 \%$ of the whole Egypt area. Therefore, there is a sever need to expanding the cultivated area either vertically or horizontally. There are some cultivated areas dominate the Egyptian oases of the West-

ern desert. One of these oases which are now under investigation is Siwa Oasis. Siwa Oasis is about $980 \mathrm{~km}^{2}$ in area, only $6 \%$ are now under cultivation, while the bed rock of the area is mainly saline or occupied by salty lakes. It has certainly the most interesting, touristic attraction of all the Egyptian Oases due to its Ancient Temple and the largest naturally flowing springs, however it suffers from several problems such as continuous deterioration of
\end{abstract}


its cultivated lands mainly due to drainage problems.

The origin and geomorphologic features of Siwa depression as well as the other depressions of the Western Desert of Egypt was discussed by a number of workers, Hume (1952), Zein El-Abdein (1952), Ibrahim (1952), Metwally (1953), Said (1962), Parsons (1963), El-Askary (1968), Gindy and El-Askary (1969), Saleh (1970), Abu El-Izz, (1971), Zakaria (1972), Harga and Hammad (1975), Gomaa, (1976) and Abdel Sammie (2000).

\section{AIM OF THE WORK}

In order to comprehend the main pathways of horizontal and vertical agricultural expansion, physical and chemical characterization of Ghazallat region soils of Siwa Oasis have to be fully investigated. Accordingly this requires studying the physical, chemical, mineralogical and radioactive properties of soils and its ability to provide the necessary nutrients for the plants.

\section{PHYSICOGRAPHIC FEATURES}

\section{Location}

Siwa Oasis is a closed depression situated in the north western portion of the Western Desert of Egypt between Long. $25^{\circ} 16^{\prime}$ and $26^{\circ} 12^{\prime} \mathrm{E}$, and Lat. $29^{\circ} 06^{\prime}$ and $29^{\circ} 24^{\prime} \mathrm{N}$. The depression floor lies at $18 \mathrm{~m}$ above sea level and located at about $300 \mathrm{~km}$ southwest of the capital of Marsa Matruh Governorate Fig. (1).

The concerned depression is bounded in the north side by an escarpment rising about $100 \mathrm{~m}$ above the depression floor and by another escarpment in the southern side that is relatively lower than the northern one, but differs from it in that it is covered with sand dunes, trending NW-SE direction. The lowest parts of the depression floor reach $18 \mathrm{~m}$ below sea level. From the west to the east, the depression floor rises gradually to merge with

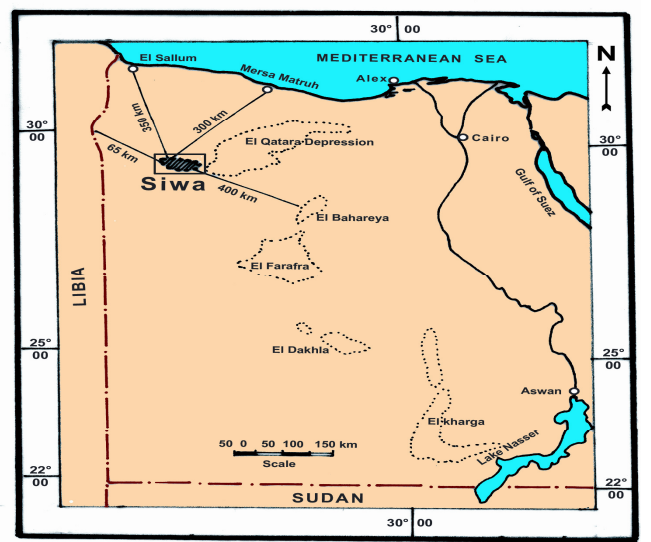

Fig.1: Location map of Siwa Oasis,Egypt

the general desert level, making it difficult to define clearly the western and eastern boundaries.

\section{Soils}

Soils of Siwa Oasis were studied by many workers, among them Zein El Aabedein (1952), Saleh (1970), Harga and Hammad (1975), Fanous (1979), Gomaa (1976) and Sherif (1979). Accordingly, the morphological and physico-chemical properties of these soils are mainly related to the parent materials forming the successive horizons of soil profiles. However, soils may differ with regard to their texture and lime (calcium carbonate) content, where the soils are formed as a result of weathering processes ( both chemical and mechanical weathering) undertaken on limestone and country rocks. Consequently calcareous materials were transported and deposited by water and wind actions. Moreover, the sandy texture mostly dominating the soil profiles is due to wind action on dunes. On the basis of the geomorphologic features of Siwa Oasis, Harga and Hammad (1975), defined the following soil groups:1-The sandy soil which are mainly found at zero contour line in the form of the crescent shape. These soils are also characterized by their shallow to medium depth, high water table and highly salt affected. 2- Deep sandy soils which are mainly located between the southern scarp and the main depression. 
These soils are slightly calcareous $\left(\mathrm{CaCO}_{3}\right.$ below 10\%) and non-saline.3- Saline soils occupying an appreciable portion of the depression and partly covered with a thick salt crust. The water table in these soils depends on their elevation and, more or less at about $100 \mathrm{~cm}$ deep. 4-Calcareous soils, which are mainly located in the eastern and western parts of the oasis. They are shallow to medium in depth, and highly salt-affected. $\mathrm{CaCO}_{3}$ content varies between 10 to $50 \%$ of the total soil matrix. 5-Hydromorphic saline sandy soils, which are mainly located at the shore-line of the old lakes. Profiles of such soils are shallow and extremely affected by salts. into:

Soils of Siwa Oasis can be differentiated

-The uncultivated soils: These include low lying areas (more than $15 \mathrm{~m}$ below sea level) of sabkhas that are highly salt affected as well as the soils which are close to sand dunes and those occupying the rocky areas.

-The cultivated soils: These soils are located between contours zero and-10 $\mathrm{m}$ above sea level.

\section{MATERIAL AND METHODS}

\section{Field Work}

On the basis of the obtained geomorphic information, interpretation of uncontrolled aerial photographs of scale 1:40.000 and geological map of scale 1:100.000, the soil samples were collected. Three soil profiles were selected to represent the main geomorphic units and their associated soil groups in the studied area, (Fig.2). These profiles were dug to about $150 \mathrm{~cm}$ depth from the surface except when rocky substrata or bedrock interfere.

\section{Soil Analysis}

Grain size distribution was determined according to the international pipette method of Piper (1950). Gravel, sand, silt and clay fractions were separated by sieving and sedimentation after removal of cementing materials. Clay and silt were separated by wet sieving from sand using $0.63 \mathrm{~mm}$ sieve. The clay and silt were transferred to one liter cylinders for pipette analysis.

\section{Chemical Analyses}

The chemical analyses include: 1-Total

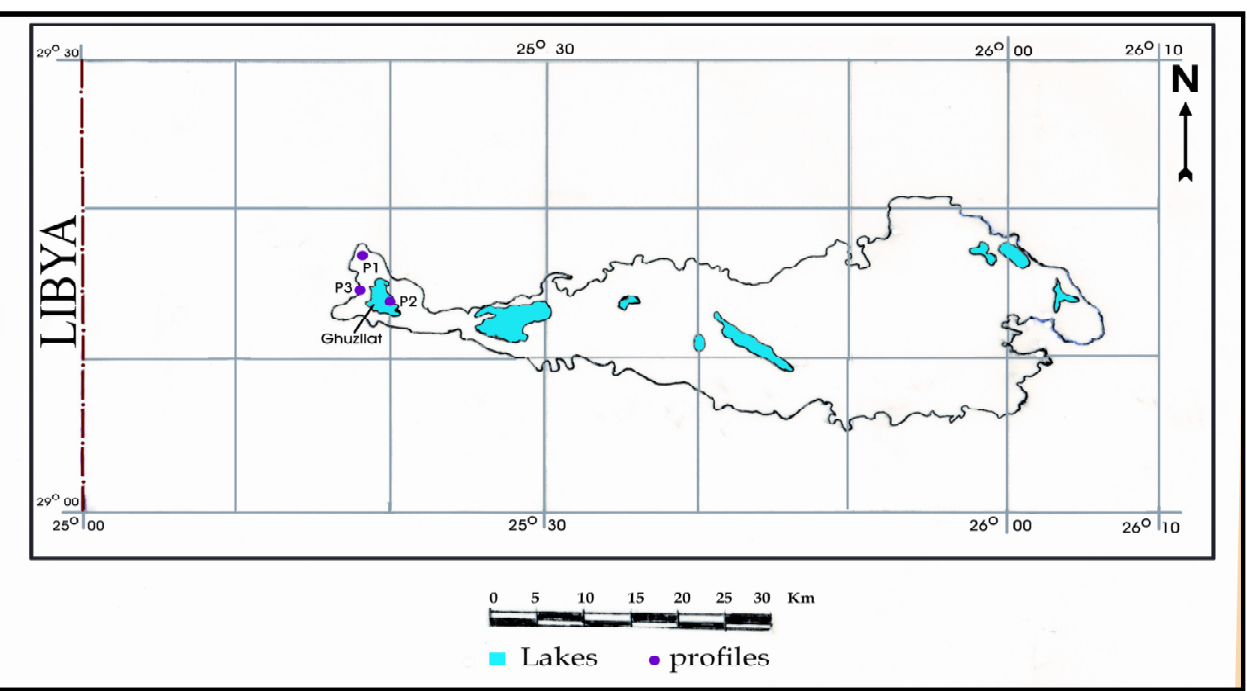

Fig.2: Location map of soil profiles, Siwa Oasis 
soluble salts determined conductimetrically in the saturated soil paste extract using the solubridge.

2- Calcium carbonate content was determined volumetrically by Collin's Calcimeter, (Piper, 1950). 3- Gypsum was determined by using the acetone method (Nelson, 1982). 4- Soil pH was measured in the soil saturation paste, (Richard, 1954). 5- Organic matter was determined according to Walkely and Black rapid titration method of Piper (1950). 6 - Total salinity (TDS) was determined through measurement of the electric conductivity in the soil extracts. 7- Cations $\left(\mathrm{Ca}^{++}, \mathrm{Mg}^{++}, \mathrm{Na}^{+}\right.$ and $\mathrm{K}^{+}$) were determined by flame photometry 8- Anions $\mathrm{CO}_{3}^{--}, \mathrm{HCO}_{3}^{-}$, and $\mathrm{Cl}$, were determined titrimetrically, but Sulphate $\left(\mathrm{SO}_{4}^{--}\right)$was calculated by difference. 9-Total nitrogen was determined by the macro-Kjeldahl apparatus as outlined by Piper (1950). 10-Avaliable P, $\mathrm{K}, \mathrm{Fe}, \mathrm{Mn}, \mathrm{Zn}$, and $\mathrm{Cu}$ were determined using ammonium bicarbonate and DEPA as an extracting solution, (Soltanpour and Schwab, 1977).

\section{Mineralogical Analyses}

1- Oriented clay samples were prepared from the separated clay as Mg-saturated airdried, Mg-saturated glycerol solvated, Ksaturated air dried and K-saturated heated to $550^{\circ} \mathrm{C}$ for 2 hours.

$\mathrm{X}$-ray diffraction technique, (XRD), was used to identify the unknown minerals using PHILIPS PW 3710/31 diffractometer, scintillation counter, $\mathrm{Cu}$-target tube and $\mathrm{Ni}$ filter at $40 \mathrm{kV}$ and $30 \mathrm{~mA}$. This instrument is connected to a computer system using X-40 diffraction program and ASTM cards for mineral identification.

Semi-quantitative estimations of identified minerals were then undertaken by measuring the under peak area as outlined by Norrish and Taylor (1962).

2- The bulk soil samples were prepared as unoriented powder mounted on glass sample holders for XRD analysis. Silt was scanned from 2 to 60 two theta degrees, (Zussman,
1977).

\section{Radiometric Analyses}

1- The radiometric study was carried out in the field by using the handling Eberline Smart Portable (ESP-1) instrument, which counts the total gamma rays emitted from the various rocks in counts per second (cps).

A multi-channel analyzer gamma ray spectrometer was used to determine the eU, eTh and $\mathrm{Ra}$ concentrations in the laboratory. The system consists of NaI-Tl Bicron scintillation detector connected with NE-4658 amplifier and a high voltage power supply with HV digital display.

All of these analyses were carried-out in Nuclear Materials Authority laboratories (NMA).

\section{RESULTS AND DISCUSSION}

Several major regions are distinguished in Siwa depression; the most important one is Ghazallat region. This region borders the oasis from the west inside El-Maraqui sector. It has many olive and palm grove gardens that are supported their irrigation water from springs and shallow wells.

\section{Textural Classes}

Ghazallat soils are characterized by textures mainly of sand and sandy loam as well as sandy clay loam in the deeper layers (Table.1).

The soils are also characterized by massive, structures, soft; non-sticky; non-plastic; moderately calcareous and involving many fine roots. This region includes three types of soils; the cultivated soils, soil under reclamation and barren soils. In this region, three soil profiles were dug and intensively studied in the field and the main characteristics features of the different soils are discussed in the following paragraphs:

\section{The Cultivated soils}

Topographically, these soils are almost flat with gentle sloping. Soil colour ranges from 
very pale-brown (10YR 7/4, dry) to light yellowish-brown (10YR 6/4, moist) in the uppermost and middle layers, while the deepest one have pale-brown (10YR 6/3, wet) colour. Soil profile (No.1) representing those soils. Soil texture ranges from sandy in the upper layer and becomes gradually sandy clay loam in the lower one.

Table 1: Particle size distribution and textural classes of the studied soil profiles of Ghazallat region

\begin{tabular}{|c|c|c|c|c|c|c|}
\hline P. No. & Type of soil & Depth (cm) & Sand \% & Silt \% & Clay $\%$ & Textural Class \\
\hline & & $0-100$ & 85.62 & 10.49 & 3.89 & $\bar{s}$ \\
\hline \multirow[t]{2}{*}{$\mathbf{P}(\mathbf{1})$} & Cultivated & $100-200$ & 85.63 & 10.84 & 3.51 & s \\
\hline & & 200-250 & 58.35 & 19.81 & 21.84 & SL-SCL \\
\hline \multirow{3}{*}{$\mathbf{P}(\mathbf{2})$} & & $0-30$ & 65.20 & 21.55 & 15.25 & SL \\
\hline & Soil under & 30-50 & 59.10 & 20.30 & 22.60 & SL-SCL \\
\hline & & $50-120$ & 41.25 & 30.31 & 28.44 & CL \\
\hline \multirow{3}{*}{ P (3) } & & $0-40$ & 89.22 & 8.29 & 2.49 & s \\
\hline & Barren soil & 40-80 & 79.50 & 17.80 & 2.70 & LS \\
\hline & & $80-200$ & 56.90 & 17.10 & 26.0 & SCL \\
\hline
\end{tabular}

\section{Soils under reclamation}

Topographically, these soils are gently undulating, very gently sloping and are dominated by black colour (10 YR2/1) in the surface layers changing to olive gray ( $5 \mathrm{Y} 5 / 2$, moist) in the deepest one (profile No.2). Soil texture ranges from sandy loam in the surface layers gradually changing with depth to SL,SCL and CL (Table.1).

\section{Barren soils}

The morphological description of this type of soils shows that these soils are characterized by drift sand surface. The average thickness of the barren soils is more than $150 \mathrm{~cm}$ and imperfectly drained. Soil colour differs from very pale-brown (10YR 8/4) to light brownish gray (10YR 6/4) in dry condition, changing to yellowish-brown (10YR 7/4) in the moist one. Generally, the soils are composed of coarse-grained sand changing into Sandy clay loam with depth and sandy clay loam in some layers.
A detailed description of these soils is given in profiles No. 1, 2 and 3 (Tables 2, 3 \& 4)

\section{Physical and Chemical Properties of the Studied Soil Profiles}

The physical and chemical analyses of the studied soil profiles in Ghazallat region (Tables $5 \& 6$ ) will discuss in the following paragraphs:

\section{Total salinity}

The approximate limits of salinity classes were defined in the Soil Survey Staff Manual (1951), Table (7).

As shown in Table (5), electrical conductivity of the soil saturation extracts (EC) of cultivated soils at Ghazallat region ranges from 4.60 up to $12.20 \mathrm{dS} / \mathrm{m}^{-1}$ at $25^{\circ} \mathrm{C}$ in the deepest

Table 2: Detailed description of soils in profile No. 1 (Cultivated soils)

\begin{tabular}{|c|c|}
\hline Location & Lat. $29^{\circ} 18^{\prime} 03^{\prime \prime} \mathrm{E}$ and Long. $25^{\circ} 19^{\prime} 09^{\prime \prime} \mathrm{N}$ \\
\hline Slope & Nearly level \\
\hline Topography & Almost flat \\
\hline Vegetation & Cultivated mainly with olive and palm trees (old farm) \\
\hline Surface cover & Aeolian sand over weathered limestone \\
\hline Drainage & Poorly drained \\
\hline Depth (cm) & Description \\
\hline $10-100$ & $\begin{array}{l}\text { Very pale-brown (10YR } 6 / 4 \text {, dry) to light yellowish } \\
\text { brown (10YR } 6 / 4 \text {, moist) sand; massive, soft slightly } \\
\text { sticky, non plastic; slightly-calcareous; abrupt smooth } \\
\text { boundary. }\end{array}$ \\
\hline $100-200$ & $\begin{array}{l}\text { Light yellowish-brown (10YR } 6 / 4 \text {, moist) sand, non- } \\
\text { sticky, non-plastic, slightly calcareous, abrupt smooth } \\
\text { boundary. }\end{array}$ \\
\hline $200-250$ & $\begin{array}{l}\text { Pale-brown (10YR 6/3, wet), sandy clay loam; massive, } \\
\text { soft, slightly sticky, slightly plastic; slightly calcareous. }\end{array}$ \\
\hline
\end{tabular}


Table 3: Detailed description of soils in profile No. 2 (Soil under reclamation)

\begin{tabular}{|c|c|}
\hline Location & Latitude $29^{\circ} 13^{\prime} 08^{\prime \prime} \mathrm{E}$ and Longitude $25^{\circ} 20^{\prime} 09^{\prime \prime} \mathrm{N}$, \\
\hline Slope & Gently sloping \\
\hline Topography & Gently undulating, \\
\hline Vegetation & Non-cultivated, \\
\hline Surface cover & Non-cultivated, \\
\hline Drainage & Imperfectly drained \\
\hline Depth $(\mathrm{cm})$ & Description \\
\hline $0-30$ & $\begin{array}{l}\text { Black (10YR 2/1, moist) sandy loam, coarse sub-angular } \\
\text { blocky, sticky, slightly plastic and friable; few fine soft } \\
\text { lime segregations; few fine to medium roots; common fine } \\
\text { spots of decomposed organic matters; abrupt smooth } \\
\text { boundary. }\end{array}$ \\
\hline $30-50$ & $\begin{array}{l}\text { Black (10YR 2/1, moist) sandy clay loam, coarse sub- } \\
\text { angular blocky, sticky, slightly plastic and friable; few fine } \\
\text { soft lime segregations; few fine to medium roots; common } \\
\text { fine spots of decomposed organic matter; abrupt smooth } \\
\text { boundary. }\end{array}$ \\
\hline $50-120$ & $\begin{array}{l}\text { Olive gray ( } 5 \text { Y } 5 / 2 \text {, moist) clay loam, coarse sub-angular } \\
\text { blocky, very sticky, very plastic, common fine soft lime } \\
\text { spots and segregations; common stains of iron oxides; few } \\
\text { fine dead roots. }\end{array}$ \\
\hline
\end{tabular}

layers falling in slightly saline to moderately saline class with specific trend throughout the soil depth. The soils under reclamation are extremely strong saline as indicated from EC values (range from $30.0 \mathrm{dSm}^{-1}$ up to 47.50 $\mathrm{dSm}^{-1}$ ). It is noticed that salinity increases gradually to the surface denoting the effect of evaporation upon drying. The barren soils are strongly saline (EC values range from 46.40 $\mathrm{dSm}^{-1}$ up to $56.50 \mathrm{dSm}^{-1}$ ).

\section{Organic matters and calcium carbonate contents}

Organic matters content in the cultivated soils ranging from $0.35 \%$ to $2.25 \%$ (Table.6), this is due to the continuous burying of the palm trees residues. Also, the organic matters content is low in soils under reclamation, (not exceed $0.52 \%$ ), while the barren soils have prevailing aridity so, they characterized by an
Table 4: Detailed description of soils in profile No.3 (Barren soil)

\begin{tabular}{ll}
\hline Location & Latitude $29^{\circ} 15^{\prime} 01^{\prime \prime}$ E and Longitude $25^{\circ} 19^{\prime} 30^{\prime \prime} \mathrm{N}$ \\
Slope & very gently sloping \\
Topography & Undulating \\
Vegetation & Scattered Hallophytes \\
Surface cover & Aeolian sand over weathered limestone \\
Drainage & Imperfectly drained \\
\hline Depth (cm) & Description \\
\hline 0-40 & $\begin{array}{l}\text { Very pale-brown (10YR8/4, dry) to pale-brown (10YR 7/4 } \\
\text { moist) sand, non-sticky, non-plastic and loose; few fine to } \\
\text { coarse residual roots; diffuse smooth boundary. }\end{array}$ \\
\hline V0-200 & $\begin{array}{l}\text { Very pale-brown (10YR7/4, moist) loamy sand, massive; } \\
\text { sticky, plastic and firm ; extremely strong reaction with } \\
\text { HCl; common medium sand pockets; few fine black spots } \\
\text { decomposed organic matters; clear smooth boundary. }\end{array}$ \\
\hline & $\begin{array}{l}\text { Very pale-brown (10YR7/4, moist) sandy clay loam, } \\
\text { massive; sticky, plastic and firm ; extremely strong } \\
\text { reaction with HCl; common medium sand pockets; few } \\
\text { fine black spots decomposed organic matter. }\end{array}$ \\
\hline
\end{tabular}

Table 5: Physical analyses of soil profiles, Ghazallat region.

\begin{tabular}{|c|c|c|c|c|c|}
\hline Profile No. & $\begin{array}{r}\text { Type of } \\
\text { soils }\end{array}$ & $\begin{array}{r}\text { Depth } \\
(\mathrm{cm})\end{array}$ & $\begin{array}{r}\text { S.P } \\
\%\end{array}$ & $\mathrm{pH}$ & $\begin{array}{r}\mathrm{EC} \mathrm{dS} / \mathrm{m} \text { at } \\
25^{\circ} \mathrm{C}\end{array}$ \\
\hline & & $0-100$ & 27.40 & 8.00 & 4.60 \\
\hline \multirow[t]{3}{*}{$\mathbf{P}(\mathbf{1})$} & Cultivated & $100-200$ & 22.00 & 7.7 & 9.90 \\
\hline & Soll & $200-250$ & 23.30 & 7.8 & 12.20 \\
\hline & & $0-30$ & 46.45 & 8.00 & 47.50 \\
\hline \multirow[t]{3}{*}{$P(2)$} & Soil under & $30-50$ & 43.20 & 7.5 & 44.30 \\
\hline & reclamation & $50-120$ & 30.00 & 7.8 & 30.00 \\
\hline & & $0-40$ & 45.40 & 7.1 & 46.40 \\
\hline \multirow[t]{2}{*}{$\mathbf{P}(\mathbf{3})$} & Barren soil & $40-80$ & 55.50 & 8.10 & 56.50 \\
\hline & & $80-200$ & 36.40 & 8.8 & 51.44 \\
\hline
\end{tabular}

negligable amounts of organic matter ranging from $0.03 \%$ to $0.08 \%$, since the high temperature and dry climate encourage the rapid decomposition of organic matters. 
Table 6: Chemical analyses of soil profiles, Ghazallat region

\begin{tabular}{|c|c|c|c|c|c|c|c|c|c|c|c|}
\hline \multirow{2}{*}{$\begin{array}{l}\text { Profile } \\
\text { No. }\end{array}$} & \multirow{2}{*}{$\begin{array}{r}\text { Depth } \\
(\mathrm{Cm})\end{array}$} & \multicolumn{2}{|l|}{$\mathrm{CaCO}_{3}$} & \multicolumn{4}{|c|}{ Anions (mg/L) } & \multicolumn{3}{|c|}{ Cations $(\mathrm{mg} / \mathrm{L})$} & \multirow{2}{*}{$\begin{array}{r}0 . M \\
\%\end{array}$} \\
\hline & & & & $\mathrm{HCO}_{3}$ & $\mathrm{Cl}$ & $\mathrm{SO}_{4}$ & $\mathrm{Ca}^{++}$ & $\mathrm{Mg}^{++}$ & $\mathrm{Na}^{+}$ & $\mathrm{K}^{+}$ & \\
\hline & $0-100$ & 29.13 & - & 4.54 & 79.84 & 41.54 & 26.73 & 16.42 & 80.50 & 2.27 & 0.39 \\
\hline \multirow[t]{3}{*}{$\mathbf{P}(\mathbf{1})$} & $100-200$ & 32.90 & - & 3.47 & 63.53 & 32.90 & 19.35 & 13.30 & 65.02 & 2.23 & 0.35 \\
\hline & $200-250$ & 34.65 & - & 2.43 & 24.38 & 12.25 & 4.85 & 2.98 & 30.03 & 1.20 & 2.25 \\
\hline & Average & 32.23 & - & 3.48 & 55.92 & 28.90 & 16.98 & 10.90 & 58.52 & 1.90 & 0.37 \\
\hline & 0.30 & 22.34 & & 2.19 & 351.67 & 150.26 & 65.29 & 58.58 & 370.95 & 9.30 & 0.34 \\
\hline \multirow[t]{4}{*}{$\mathbf{P}(2)$} & $30-50$ & 43.35 & - & 3.76 & 318.33 & 147.85 & 55.45 & 46.65 & 360.96 & 6.88 & 0.51 \\
\hline & $50-120$ & 47.90 & - & 2.13 & 190.50 & 119.05 & 43.42 & 42.99 & 218.79 & 6.48 & 0.52 \\
\hline & Average & 37.86 & - & 2.69 & 274.83 & 139.05 & 54.72 & 49.41 & 316.9 & 7.55 & 0.47 \\
\hline & $0-40$ & 16.95 & $\because$ & 3.60 & 324.61 & 170.24 & 63.53 & 93.73 & 320.09 & 21.10 & 0.15 \\
\hline \multirow[t]{3}{*}{$\mathbf{P}(\mathbf{3})$} & $40-80$ & 14.70 & . & 3.76 & 408.36 & 204.85 & 65.10 & 61.94 & 470.83 & 19.10 & 0.06 \\
\hline & $80-200$ & 19.10 & - & 2.45 & 8.35 & 5.88 & 3.23 & 0.95 & 11.85 & 0.65 & 0.03 \\
\hline & Average & 16.92 & - & 3.27 & 247.11 & 126.99 & 43.95 & 52.21 & 267.59 & 13.62 & 0.08 \\
\hline
\end{tabular}

Table 7: Classification of saline soils, (Soil Survey Staff Manual, 1951).

\begin{tabular}{lrr}
\hline Class & Class Name & $\begin{array}{r}\mathrm{EC} \mathrm{dSm}^{-1} \text { at } \\
25^{\circ} \mathrm{C}\end{array}$ \\
\hline 0 & Salt Free & $0-4$ \\
1 & Slightly Saline & $4-8$ \\
2 & Moderately & $8-15$ \\
& Saline & \\
3 & Strongly Saline & $>15$ \\
\hline
\end{tabular}

Calcium carbonate $\left(\mathrm{CaCO}_{3}\right)$ values range from $29.13 \%$ to $34.65 \%$ in cultivated soils, profile (1), but from $22.24 \%$ to $47.90 \%$ in soils under reclamation, while they range from $14.70 \%$ to $19.10 \%$ in the barren soils (Table.6). The soils therefore are highly calcareous.

The enrichment of $\mathrm{CaCO}_{3}$ in the subsurface horizons of cultivated and under reclamation soils is apparently not pedogenic as these soils are young and usually under wet conditions.

\section{Soil reaction}

Table (5) shows that the soil reaction of the cultivated and under reclamation soils is mildly to moderately alkaline $(\mathrm{pH}$ values range from 7.1 to 8.00 ). The barren soils are characterized by a highly alkaline as indicated from $\mathrm{pH}$ values which range from 7.1 to 8.80 (Table.5).

\section{Cationic and anionic composition}

Soluble calcium $\left(\mathrm{Ca}^{++}\right)$is often dominating cation followed by $\mathrm{Mg}^{++}$and $\mathrm{Na}^{+}$cation, while $\mathrm{K}^{+}$is the least soluble cation in all profiles. We can be notice that $\mathrm{Na}^{+}$cation $>\mathrm{Mg}^{++}, \mathrm{Na}^{+}>$ $\mathrm{Ca}^{++}$and $\mathrm{Mg}^{++}$. The predominance of $\mathrm{Na}^{+}$and $\mathrm{Mg}^{++}$is a good reflection of the involvement of marine origin of the soils formation. On the other hand, the anionic distribution has the following descending order $\mathrm{Cl}^{-}$anion $>\mathrm{SO}_{4}$ ${ }^{-}>\mathrm{HCO}_{3}^{-}$, where $\mathrm{CO}_{3}^{--}$is neglected (Fig.3). This indicates that sodium chloride is the predominant salt followed by calcium sulphate.

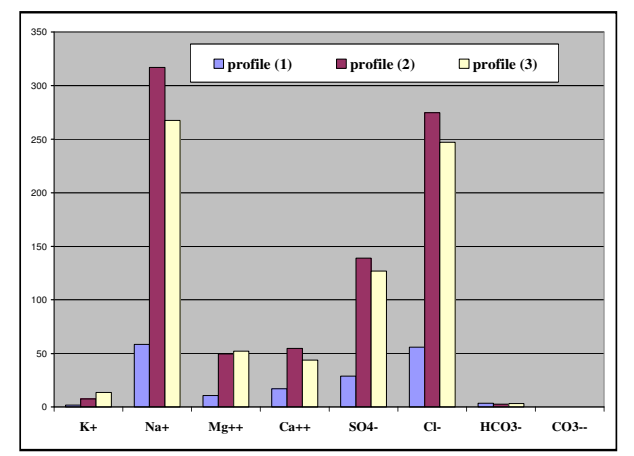

Fig. 3: Averages of cations and anions variability bar diagram (in $\mathrm{mg} / \mathrm{L}$ ) of soil profiles, Ghazallat region

\section{Distribution of Fertility Elements (NPK)}

According to Okalebo et al., (1993), the values of total nitrogen in cultivated soils in Ghazallat region (profile No.1) indicate low to moderate levels (range from $0.09 \%$ up to $0.16 \%$, (Table. 8 ).

Available phosphorous content ranges from $7.22 \mathrm{ppm}$ to $12.0 \mathrm{ppm}$, while potassium 
Table 8: Distribution of fertility elements of soil profiles, Ghazallat region.

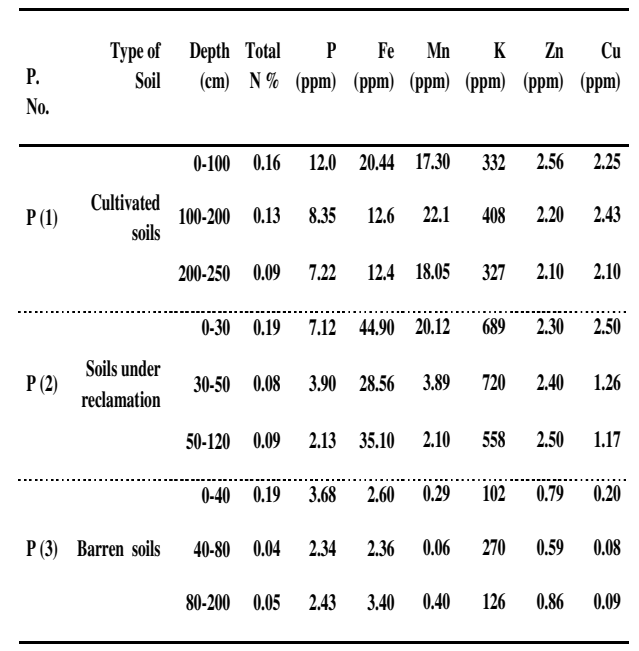

ranges from 327 ppm to 408 ppm. Iron, manganese, zinc and copper elements occur in adequate levels (Table.8).

According to Soltanpour and Schwab (1977), the studied soils have an adequate level of iron, manganese and copper, while zinc is present in low to adequate levels.

In the soils under reclamation (profile No.2), it is clear that total nitrogen exhibits low to moderate levels $(0.08 \%$ to $0.19 \%)$, (Table. 8 ). Phosphorous ranges from moderate level in the surface layer to very low level in the sub-surface layer (7.12ppm to $2.13 \mathrm{ppm}$ ) to adequate levels (4.66 ppm to $14.89 \mathrm{ppm}$ ), while available potassium has high levels (558 ppm to $720 \mathrm{ppm}$ ). Available iron, manganese, zinc and copper are present in adequate levels ranging from (28.56 to $44.90 \mathrm{ppm}),(2.10$ to $20.12 \mathrm{ppm}),(2.30$ to $2.50 \mathrm{ppm}$ ) and (1.17 to $2.50 \mathrm{ppm}$ ) respectively.

Concerning soil fertility in the barren soil of Ghazallat region (profile No.3), we can be noticed that, the total nitrogen occurs in low to moderate levels as its values vary widely from $0.05 \%$ to $0.19 \%$. Available phosphorous ranges from very low to moderate levels, while available potassium has moderate to high levels (102 ppm to $270 \mathrm{ppm}$ ). Available iron is found in the marginal levels (2.36 ppm to $3.68 \mathrm{ppm})$, while available manganese is found in low to adequate levels ranging from $(0.06 \mathrm{ppm}$ to $0.40 \mathrm{ppm})$. Zinc is present in low levels $(0.59$ ppm to $0.86 \mathrm{ppm}$ ), while cupper is found in very low amounts, not exceeding $0.20 \mathrm{ppm}$.

\section{Mineralogical Composition \\ Mineralogical composition of bulk soil samples}

Total soil samples (bulk samples) and oriented clay fractions were analyzed using $\mathrm{X}$-ray diffraction technique in order to evaluate aspects of soil genesis and formation.

Analyses of the bulk soil samples led to identify the essential minerals in the studied profiles. X-ray analysis data of some soils from Ghazallat region are listed in (Table.9) and Figs. (4 and 5).

The obtained data indicates that quartz, calcite, feldspars (albite) minerals are the main dominant mineral associations in all soil profiles of Ghazallat region. Dolomite and anhydrite as well as gypsum are present in some depths of soil profiles.

Quartz gives diffraction line at 4.26 besides a strong second order peak at $3.34 \AA$.

Table 9: Mineralogical composition of the bulk soil samples of the studied soil profiles

\begin{tabular}{|c|c|c|c|c|c|c|c|}
\hline P. No. & Depth $(\mathrm{Cm})$ & Quartz & Calcite & Albite & Dolomite & Anhydrite & Gypsum \\
\hline & $0-100$ & * & * & & * & & \\
\hline \multirow[t]{3}{*}{$P(1)$} & $100-200$ & * & * & * & * & & \\
\hline & $200-250$ & * & * & * & & & \\
\hline & $0-30$ & * & * & $*$ & & & $*$ \\
\hline \multirow[t]{3}{*}{$P(2)$} & $30-50$ & * & * & * & & $*$ & * \\
\hline & $50-120$ & * & * & * & & & \\
\hline & $0-40$ & $*$ & $*$ & $*$ & $*$ & $*$ & $*$ \\
\hline \multirow[t]{2}{*}{$P(3)$} & $40-80$ & * & * & * & * & * & * \\
\hline & $80-200$ & * & * & * & * & & \\
\hline
\end{tabular}




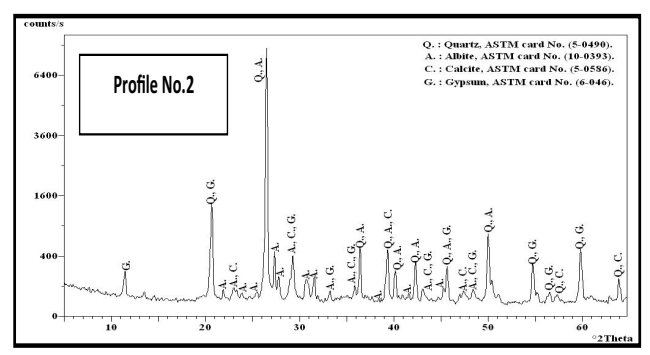

Fig.4 : X-ray diffractogram of quartz, albite, calcite and gypsum minerals from soil profile (No. 2) from Ghazallat region

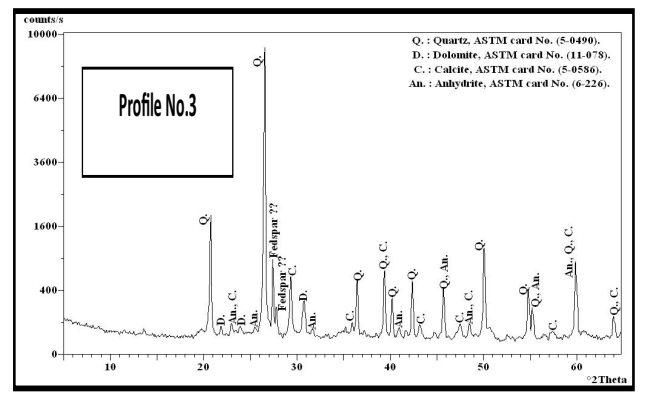

Fig. 5: X-ray diffractogram of quartz, dolomite, calcite and anhydrite minerals from soil profile (No.3) from Ghazallat region

The diffraction doublets about 3.22 to $3.24 \AA$ beside an overlapped peak at $4.25 \AA$ denote the presence of feldspars.

Calcite $\left(\mathrm{CaCO}_{3}\right)$ is a carbonate mineral and also the most stable polymorph of calcium carbonate. The other polymorphs are the minerals aragonite and vaterite. The peaks at $3.03 \AA$ and the relatively weak one at $2.49 \AA$ confirmed the presence of calcite in all samples of the soils of Ghazallat region.

Albite $\left(\mathrm{NaAlSi}_{3} \mathrm{O}_{8}\right)$ is a plagioclase feldspar mineral. It is the sodium end member of the plagioclase solid solution series.

Dolomite $\left\{\mathrm{Ca} \mathrm{Mg}\left(\mathrm{Co}_{3}\right)_{2}\right\}$ is a carbonate mineral composed of calcium magnesium carbonate . Dolomite mineral is identified by the presence of broad peaks at $2.89 \AA, 2.19 \AA$ and $1.79 \AA$, respectively Anhydrite is a mineral - anhydrous calcium sulfate $\left(\mathrm{CaSO}_{4}\right)$.
Anhydrite is most frequently found in evaporite deposits with gypsum and associated with calcite, halite and sulfides

Gypsum $\left(\mathrm{CaSO}_{4} \cdot 2 \mathrm{H}_{2} \mathrm{O}\right)$ is a very soft mineral composed of calcium sulfate dihydrate. It is often associated with halite and sulfur minerals.

Based on the foregoing presentation of soil mineralogy, we can conclude that the occurrence of quartz, feldspars and dolomite may be referred to the nature of parent materials forming the soils in Ghazallat region. Here, it is worth to mention that the dominance of quartz relative to feldspars is attributed to susceptibility to weathering.

\section{Clay fractions analysis}

X-ray diffraction analysis of the clay fractions that separated from the studied soil profiles of Ghazallat region is shown in (Table. 10) and (Figs. 6, 7, and 8). Interpretation of $\mathrm{X}$-ray diffraction patterns is based on the presence of characteristic diffraction peaks for each mineral in the clay sample. The criteria used for clay mineral identification are those mentioned by Brown (1961), Jackson (1973), Dixon and Weed, (1977) and Wilson, (1987).

For further differentiation, semi quantitative estimation of the identified minerals was performed. The data of the semi quantitative mineralogical composition of the clay fraction are shown in (Table.10). It is clear that illite and kaolinite represent the identified clay minerals in the studied soil samples.

Illite $(\mathrm{K}, \mathrm{H} 3 \mathrm{O})(\mathrm{Al}, \mathrm{Mg}, \mathrm{Fe})_{2}(\mathrm{Si}, \mathrm{Al})_{4} \mathrm{O}_{10}(\mathrm{OH})_{2}(\mathrm{H} 2 \mathrm{O})$ represents the dominant mineral (Figs.6,7 and 8 ) in all of the studied soil profiles in Ghazallat region. It gives a diffraction peaks at 9.96 $\AA$ to $10.28 \AA$ in the $\mathrm{Mg}$-saturated samples and remains constant in the other treatments. Admixture of quartz is characterized with high sharp peak at $3.35 \AA$ through all treatments.

Illite is non-expanded clay-sized micaceous mineral. It is a phyllosilicate or layered 
alumino-silicae. Structurally, illite is quite similar to muscovite with less potassium and more water

Kaolinite and illite occurences are reported by Hammad and Harga (1976) in a study of the soils of Siwa Oasis. Beside these two minerals, palygoeskite was identified. The former mineral was attributed in the study to

Table 10: Semi quantitative estimation of the clay minerals composition.

\begin{tabular}{|c|c|c|c|}
\hline $\begin{array}{l}\text { Profile } \\
\text { No. }\end{array}$ & $\begin{array}{r}\text { Depth } \\
\text { (Cm) }\end{array}$ & Kaolinite & Illite \\
\hline & $0-100$ & ++ & +++ \\
\hline \multirow[t]{3}{*}{$\mathbf{P}(\mathbf{1})$} & $100-200$ & & ++ \\
\hline & $200-250$ & ++ & ++ \\
\hline & 0-30 & ++ & +++ \\
\hline \multirow[t]{3}{*}{$\mathbf{P}(2)$} & $30-50$ & & +++ \\
\hline & $50-120$ & & ++ \\
\hline & $0-40$ & ++ & +++ \\
\hline \multirow[t]{2}{*}{$\mathbf{P}(3)$} & $40-80$ & + & ++ \\
\hline & 80-200 & & + \\
\hline
\end{tabular}

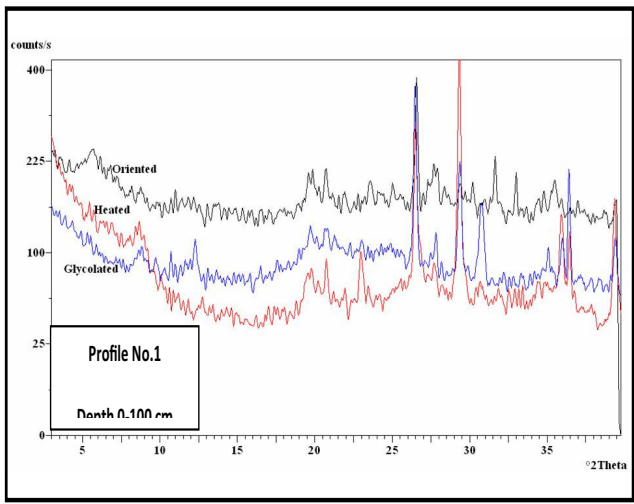

Fig. 6: X-ray diffraction pattern of $<2 \mu$ clay fraction separated from profile No. (1), showing illite and Kaolinite minerals, Ghazallat region

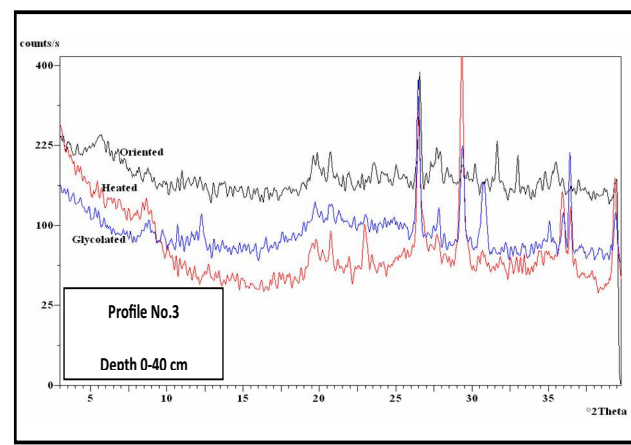

Fig. 7: X-ray diffraction pattern of $<2 \mu$ clay fraction separated from profile No. (3), showing illite and Kaolinite minerals, Ghazallat region

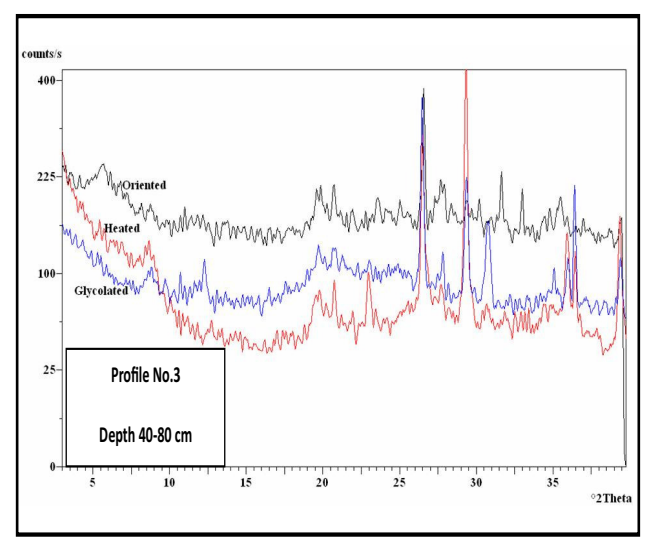

Fig. 8: X-Ray Diffraction Pattern of $<2 \mu$ clay fraction separated from profiles No. (3) showing illite and kaolinite minerals, Ghazallat region

a calcareous and brine environments.

Kaolinite is formed in soils under acid wet conditions which is not prevailing under the present environment in Siwa Oasis. The soils there are formed due to weathering of the exposed rocks in the depression encouraged by a high water table. Kaolinite can be contains very small traces of $\mathrm{U}$ and $\mathrm{Th}$, therefore, useful in radiological dating.

Kaolinite gives a strong spacing at 7.16 $\AA$ and $3.57 \AA$ in the Mg-saturated samples and disappear upon heating to $550^{\circ} \mathrm{C}$ for four hours. 


\section{RADIOMETRIC STUDIES}

However, uranium seems to be more easily leached than its daughter $\mathrm{Ra}^{226}$ and than $\mathrm{Th}^{232}$, (Baweja et al., 1987). Soil surveyors do not include in their activities information about their radioactivity levels. It is very important to establish criteria to define elevated concentrations in the agricultural environment, (Arkipovet et al., 1986, Drichko and Lisachenko, 1984, Talibudeen, 1964 and Graham, 1964).

Charters et al. (1991) reported that the highly weathered soil near uranium mine would have relatively high uranium content because of their small contents of clay, organic matters, iron content as well as acidic $\mathrm{pH}$ values. They (Op. Cit.) reported variable values for uranium content in soils ranging from less than 1 $\mathrm{ppm}$ to $8 \mathrm{ppm}$. Then, they concludes that any soil has average uranium content more than that average can be called as uraniferous soil. IAEA, (1988) reported also that some specific plants tend to accumulate uranium (U) as well as selenium, $(\mathrm{Se})$, and sulpher, $(\mathrm{S})$.

\section{Distribution of Uranium and Thorium}

The studied soil profiles were analyzed using gamma-ray spectrometric techniques for measuring their uranium, thorium and radium contents.

Table (11) shows the $\mathrm{eU}^{238}, \mathrm{eTh}^{232}$ and $\mathrm{Ra}^{226}$ contents as well as eTh/eU ratios of the studied soil profiles from Ghazallat region. Profile (P.1) has an eU average content reaching 2.67 ppm, an average eTh content of 5 ppm and average Ra content of 1.89 ppm, while the average of $\mathrm{Th} / \mathrm{U}$ ratio is 1.87 . Profile (P.2) has average eU; eTh and $\mathrm{Ra}$ contents reaching about 4, 33 ppm, 7.67 ppm and 3 respectively, with an average eTh/eU ratio of 1.77 . The average eU contents in profile (P.3) is $3.67 \mathrm{ppm}$, the average of eTh content is 7 ppm and the average Ra content is $2.67 \mathrm{ppm}$, while the average $\mathrm{eTh} / \mathrm{eU}$ ratio is 1.90 .

These means that all of the studied soils in the area are not related to the uraniferous soils (not exceed 6ppm of uranium content).

\section{Uranium and Thorium Relationships}

The relationship of uranium against thorium may clarify the enrichment or depletion of uranium and/or thorium. The plotting of eU against eTh of selected samples (Fig.9) shows a positive relation. All of the studied samples plot in the field of $\mathrm{eTh} / \mathrm{eU}$ greater than 1 (Table.11), which means the depletion of eU relative to eTh. We can be noticed that, there are no any accessory minerals bearing uranium or thorium as well as no any secondary uranium minerals in such samples due to the depletion on their contents of eU and eTh. These means that, all of the studied soil samples are not related to uraniferous soils.

Normally, eTh is three times as abundant as uranium in natural rocks (Darnely, 1982). When this ratio is disturbed, it indi-

Table 11: eU, eTh and Ra Contents as well as eTh/eU Ratio of Soil Samples from Ghazallat Region.

\begin{tabular}{|c|c|c|c|c|c|}
\hline Profile No. & $\begin{array}{l}\text { Depth } \\
(\mathrm{Cm})\end{array}$ & $\begin{array}{r}\mathrm{eU} \\
(\mathrm{ppm})\end{array}$ & eTh (ppm) & $\begin{array}{r}\mathrm{Ra} \\
(\mathrm{ppm})\end{array}$ & $\mathrm{eTh} / \mathrm{eU}$ \\
\hline & $0-100$ & 3 & 5 & 3 & 1.67 \\
\hline $\mathrm{P}(1)$ & $100-200$ & 2 & 4 & 2 & 2.00 \\
\hline \multirow[t]{3}{*}{ Cultivated Soils } & $200-250$ & 3 & 6 & 3 & 2.00 \\
\hline & Average & 2.67 & 5 & 2.67 & 1.87 \\
\hline & $0-30$ & 3 & 7 & 3 & 2.33 \\
\hline $\mathrm{P}(2)$ & $30-50$ & 4 & 8 & 3 & 2.00 \\
\hline \multirow[t]{3}{*}{$\begin{array}{l}\text { Soils under } \\
\text { reclamation }\end{array}$} & $50-120$ & 6 & 8 & 3 & 1.33 \\
\hline & Average & 4.33 & 7.67 & 3 & 1.77 \\
\hline & $0-40$ & 4 & 7 & 2 & 1.75 \\
\hline $\mathrm{P}(\mathbf{3})$ & $40-80$ & 3 & 6 & 3 & 2.00 \\
\hline \multirow[t]{2}{*}{ Barren Soils } & $80-200$ & 4 & 8 & 3 & 2.00 \\
\hline & Average & 3.67 & 7 & 2.67 & 1.90 \\
\hline
\end{tabular}

$\mathrm{eU}={ }^{238} \mathrm{U}, \quad \mathrm{eTh}={ }^{232} \mathrm{Th}, \quad \mathrm{Ra}={ }^{226} \mathrm{Ra}$ 
cates the depletion or enrichment of eU. This is very evident in the analyzed soil samples of all types (cultivated soils, soil under reclamation and barren soils), where the increasing in $\mathrm{eTh} / \mathrm{eU}$ ratios is accompanied by depletion in uranium, hence a negative relation exists. So, the variation diagrams (Figs.9 and 10) indicate that that all of the studied soil samples are very poor in the radioactive elements which cause very harmful diseases.

\section{CONCLUSIONS}

Ghazalat area represents one of the most promissing parts of Siwa Oasis for agricultural development because of it covers wide area with good topography and low releif, sand and
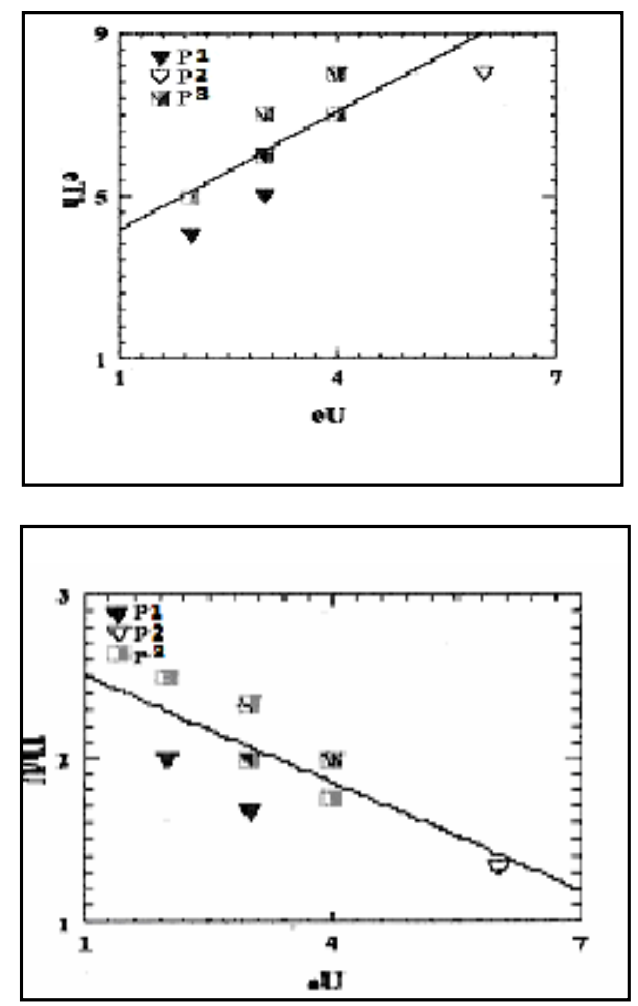

Fig. 9: eU-eTh binary diagram of soil samples and $\mathrm{eU}-\mathrm{eTh} / \mathrm{eU}$ variation diagram for soil samples Ghazallat region. sandy loam as well as sandy clay soil texture. In the same time, its soils contain some illite and kaolinite clay minerals and valiable elemnts that are nessesary for agriculture as $\mathrm{K}, \mathrm{Ph}, \mathrm{N}, \mathrm{Zn}$ and $\mathrm{Ca}$ with different values and the irrigation water are also available. The study clears that the development of the area needs to adding some natural as well as artificial fertilizers.

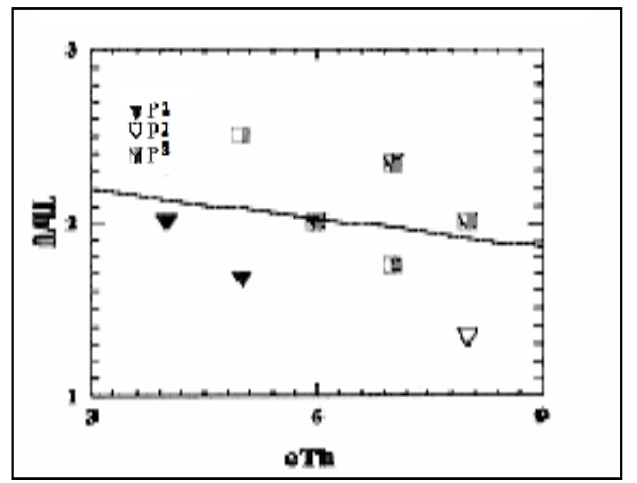

Fig. 10: eTh-eTh/eU variation diagram for soils samples, Ghazallat region

\section{REFERENCES}

Abdel Samie, M.K.,2000. Classification and Evaluation of Siwa Oasis Soils. Ph.D Thesis, Fac. Agric., Ain Shams Univ., Egypt.

Abu Al-Izz., M.S.,1971. Landforms of Egypt. The Amer. Univ., Cairo Press, 282p.

Arkhipov, N.P.; Fedorova, T.A., and Fealeva, L.T.,1986. Relative amounts of compounds of heavy natural radionuclides. Sov. J. Soil Sci, 18, 66-70.

Baweja, A.S.; Joshi, S.R., and Demayo, A.,1987. Radionculide content of some Canadian surface waters: A report in the national radionuclide monitoring program, 1981-1984, Scientific series No.156. Inland Water/Lands Directorate, Water Quality Branch, Ottawa, Canada.

Brown, G.,1961. The X-ray identification and crystal structure of clay minerals. Mineral. Soc. of Great Britain, Monograph, London, U K.

Charters, C.J.; Walker, P.H.; Willett, I.R.; East, 
T.J.; Cull, R.F.; Talsma, T., and Band, W.J., 1991. Soil and hydrology of ranger uranium mine sites in relation to application pond water. Tech. Memo., 34. Supervising Scientist for the Allingator Rivers Region. Australian. Gor. Publ. Service, Canberra.

Darnely, A.G.,1982. Hot granites, Some general remarks. In: Uranium In Granites (Maurice, Y.T. Ed.): Geol. Surv. Can., 81 (23), 1-10.

Dixon, J.B., and Weed, S.O.,1977. Minerals in soil environments. Soil Sci Amer. Modison, Wisconsin, USA.

Drichko, V.F., and Lisachenko, E.P.,1984. Background concentration of ${ }^{226} \mathrm{Ra},{ }^{238} \mathrm{Th}$ and ${ }^{40} \mathrm{~K}$ in cultivated soils and agricultural plants. Sov. J. Ecol., 15, 81-85.

El-Askary, M.A., 1968. Some geological studies on Siwa depression, Western desert, UAR. M. Sc. Thesis, Fac. Sci., Alex. Univ., Egypt.

Fanous, N.E., 1979. Mineralogical studies of some soils of Siwa. M. Sc. Thesis, Fac. Agric., Ain Shams Univ., Egypt.

Gindy, A.R., and El Askary, M.A.,1969. Stratigraphy, structure and origin of Siwa Depression, western Desert of Egypt. Bull. Amer. Assoc. Petrol, Geol., 53, 603-625.

Gomaa, A.E.,1976. Physical characterization of Siwa soils. M. Sc. Thesis Fac. Agric., Cairo Univ., Egypt.

Graham, E.R.,1964. Radioistopes and soils. In: Chemistry of the soil (Bear F.E., Ed.): Rainhold Pub. Corp., New York., Sinai., $3^{\text {rd }}$ Scientific Arab Conf., Beirut, 350-355 (in Arabic).

Hammad ,M.A. and Harga,A.,1976. Mineralogical assesment of soil origin and formation in Siwa Oasis, Egypt.Al Azhar Agricu. Res. Bull..

Harga, A.A.; Hammad, M.A.M., and Abdel Salam, M.A.,1975. The soils of Siwa Oasis. Desert Inst. Bull., ARE, 25(1\&2), 173-186.

Hume, W. F.,1952. geology of Egypt. Government Press. Bull.1. Cairo, UAR.
International Atomic Energy Agency (IAEA), 1988. Geochemical exploration for uranium. Tech. Report Ser., No.284.

Ibrahim, M.M.,1952. The effect of static electric charges on wind erosion and the origin of the depressions in Libyan Desert. Cairo privately printed Work., Egypt.

Jackson, M.L.,1973. Soil chemical analysis. prenceHall, Inc, Englewood Cliffs, M.J., USA.

Metwally, M.,1953. A physiographic features of the Oasis of the Libyan Desert. Bull. Inst. Desert Egypte, Tom 111, No. 2, 143-163.

Nelson, R.E.,1982. Carbonate and gypsum. In: Chemical and microbiological properties (L. Page, L. Ed.). $2^{\text {nd }}$ Am. Soc. Agron., Inc. Madison, Wisconsin, USA., 181-196.

Norrish, K., and Taylor, R.M.,1962. Quantitative analysis by X-Ray diffraction. Clay Miner Bull., 5, 98p.

Okalebo, J.R.; Gathua, K.W., and Woomer, P.L,1993. laboratory methods of soil and plant analysis. A working manual. Soil Sci. of East Africa. Technical pulp. No.1. Nairobi, Kenya, $88 \mathrm{p}$.

Parsons, R.M.,1962. The Ralph N parsons Engineering company "final report, Siwa Oasis Area" New valley project, Western.

Piper, C.S.,1950. Soil and plant analysis, Interscience Pub. Inc., New York.

Richard, L.A.,1954. Diagenesis and improvement of saline and alkali soils. U.S. Dept. Agric., Handbook No.60, 160p., Washington D.C., USA.

Said, R.,1962. The geology of Egypt: Elsevier, New York, 337p.

Saleh, H.H., 1970. Pedological study on Siwa Oasis soils. M. Sc. Thesis. Fac. Of Argic., Cairo Univ.

Sherif, M.A., 1979. Evaluation for fertility status in soils of Siwa Oasis. M.Sc. Thesis, Fac. Agric., 
Ain Shams Univ., Egypt.

Soil Survey Staff Manual, 1951. Soil Survey Manual . U. S. Dep agric. Handbook no. 18,503 p., illus, Washington.

Soltanpour, P.N., and Schwab, A.P.,1977. A new soil test for simultaneous extraction of macroand micro-nutrients in alkaline soils. Common in soil Sci., and plant analysis, 8*3, 195-207.

Talibudeen, O.,1964. Natural radioactivity in soils. Soils \& Fert., 27, 347-359.

Wilson, M.J.,1987. X-ray powder diffraction meth- ods, in determinative methods of clay mineralogy( Wilson, M.J., Ed.): Blacke and Son Ltd., New York.

Zakaria, M.H., 1972. Geological and Hydro-geological Studies of Siwa Oasis. M. Sc. Thesis, Fac. Sci., Alex. Univ., Egypt.

Zein El-Abdein, A.,1952. The soil of Siwa oasis. Fac. Of Agric., Cairo Univ.mNo.10.

Zussman, J.,1977. X-Ray diffraction in physical methods in determinative Mineralogy, $2^{\text {nd }} e d$. , (Zussman, J., Ed.). Academic Press, London, 261-334.

$$
\begin{aligned}
& \text { الخواص الطبيعية والكيميائية لمنطقة غزلات، واحة سيـوه، الصحراء الغزبية، مصر } \\
& \text { محمد أحمد حماد ، محمد عبد السلام حسين ، مصطفى السيد درويش ، فتحي علي عمار و عادل جمال أحمد } \\
& \text { و احة سيوه أحد منخفضات الصحر اء الغربية و هي منخفض مغلق يقع في الجزء الثمالي الغربي من الصحر اء واء }
\end{aligned}
$$

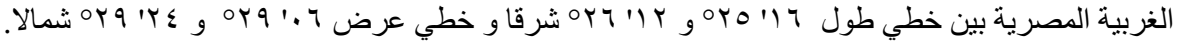

$$
\begin{aligned}
& \text { تم اختيار ثلاثة قطاعات للار اسة من نربة منطقة الغزالات ممثلة للوحدات الوصفية والمكونات الأساسية التابعة لهذه } \\
& \text { التربة ومن خلال الدراسة تبين أن هذه التربة تتميز بالنسيج الرملى والرة الرملى الجئ الجيرى بالإضافة الى النسيج الرملى الطينى }
\end{aligned}
$$

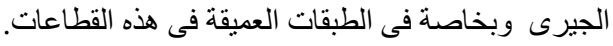

$$
\begin{aligned}
& \text { وقد أوضحت التحليلات ان تربة منطقة غز الات ثلاثة انواع و هى تربة صالحة للزر اعة و تربة قابلة للإستصلاح }
\end{aligned}
$$

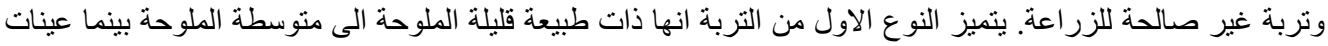

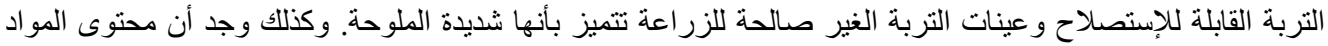

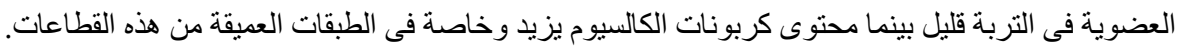

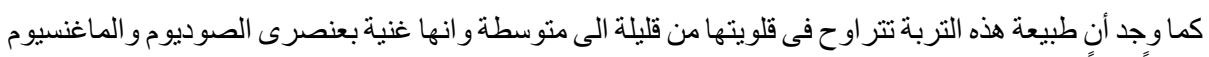

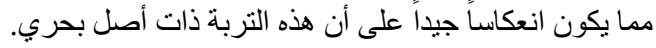

$$
\begin{aligned}
& \text { وقد وجد أيضاً من خلال التحليلات الكيميائية أن مجمو عات العناصر المخصبة (NPK) تتر اوح من مستويات قليلة } \\
& \text { الى منوسطة. } \\
& \text { كذلك دلت الدر اسات المعدنية على أن التربة محل الدر اسة غنية بمعادن الكوارنز والكالسيت وبعض الفلسبار ات }
\end{aligned}
$$

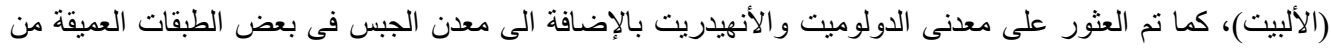

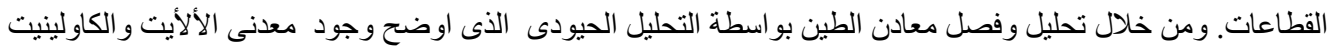

$$
\begin{aligned}
& \text { وقد دلت ايضا الدراسات الإشعاعية أن جميع أنوع التربة المدروسة لا تنتمى الى التربة المشعة حيث لا يتجاوز } \\
& \text { المحتوى اليور انيومى بها عن } 7 \text { جزء من المليون. }
\end{aligned}
$$

